\title{
“Lès-Poésie?”: Levinas Reads La folie du jour
}

Maurice Blanchot's short narrative "Un récit" - or "Un récit?": the difference has attracted considerable comment - first appeared in the short-lived Parisian review Empédocle in May 1949, and was reissued by Fata Morgana under the definitive title La folie $d u$ jour in $1973 .{ }^{1}$ Only as a little book, published in the wake of May 1968 and at a highpoint of Blanchot's intellectual standing in France, did it begin to attract attention beyond avant-garde literary circles. ${ }^{2}$ One significant instance of this new awareness and esteem is Emmanuel Levinas's "Exercices sur 'La folie du jour,"” which was published in the February 1975 number of Change and became the final of four texts devoted to his old friend gathered in Sur Maurice Blanchot (1975). That Levinas admired Blanchot's narrative works, especially the first edition of Thomas l'obscur (1941), is amply testified, not least by the wartime notes written in captivity in which he planned to launch a career as a novelist. ${ }^{3}$ And that, after the war, he distanced himself from most art, including a great deal of literature, is also evident from even the most cursory reading of "La réalité et son ombre" (1948). "Art," he writes in that fierce essay, is "essentially disengaged, is a dimension of escape in a world of initiative and responsibility" and, worse, "There is something nasty, selfish, and cowardly in artistic pleasure" (Levinas 2004, 89, 90).

Yet Blanchot largely evades his friend's strictures because his work disrupts any authorial pretension to classical literary mastery and le beau style. There is a world, Levinas tells us in 1971, in which "no human suffering keeps from being in order [n'empêche de s'ordonner]," and yet in the same breath he recognizes that Blanchot "reminds that world that its totality is not total - that the coherent discourse it vaunts does not catch up with another discourse which it fails to silence." In the five brief sentences that follow he nicely captures much of what Blanchot wishes to tell us.

1 In particular, see Jacques Derrida, “Title to be Specified” (2011, 214-215).

2 One index of the esteem in which Blanchot was held at this period is the special issue of Critique (volume 229, June 1966) that was consecrated to his work.

3 See Emmanuel Levinas, Oeuvres, 1: Carnets de captivité et autre inédits (2009, 98). 
That other discourse is troubled by an uninterrupted noise. A difference does not let the world sleep, and troubles the order in which being and non-being are ordered in a dialectic. This Neuter is not a someone, nor even a something. It is but an excluded middle that, properly speaking, is not even [n'est même pas]. Yet there is more transcendence than any world-behind-the-worlds ever gave a glimpse of.

(Levinas 1996, 154-155)

Presumably religious transcendence merely ends in a higher state of immanence, and this is not so with the Neuter.

Earlier, in "Le regard du poète" (1956), a long review of L'Espace littéraire (1955), Levinas was more nuanced in his estimation of his friend's achievement. He drew attention, amid much insight and much praise, to a squint in Blanchot's gaze. The stricture is less to do with him as a reader of Mallarmé and Kafka, Hölderlin and Rilke, than as a diagnostician of the figure of the modern writer, in particular the ground - which for Levinas is at best a playground - for his or her authenticity. "If the authenticity Blanchot speaks of is to mean anything other than a consciousness of the lack of seriousness of edification," Levinas pointedly says, "anything other than derision - the authenticity of art must herald an order of justice, the slave morality that is absent from the Heideggerian city" $(1996,137)$. Presumably, Blanchot's narrative writing up to that time, from Thomas l'obscur (1941) to Celui qui ne m'accompaignait pas (1953), including "Un récit" (1948), announces, directly or indirectly, positively or negatively, "an order of justice." The same cannot be said for all of his critical writing, it seems.

What upsets Levinas when reading L'Espace littéraire? He seizes upon a footnote towards the end of the book, where Blanchot specifies the artist's mission. An artist should "call us obstinately back to error, to turn us toward that space where everything we propose, everything we have acquired, everything we are, all that opens upon the earth and in the sky, returns to insignificance, and where what approaches is the nonserious and the nontrue, as if perhaps thence sprang the source of all authenticity"(1982, 247 note 8). "Error" here is written in full awareness of its root in Latin, errare, "to wander, to go astray." The art we need today, art that is nourished by Lautréamont and Sade, as well as by the authors already mentioned, enables us to move away from a world fixed by God or the gods, from traditional norms of literature, even from "being" as rigorously determined by philosophers such as Hegel and, above all, Heidegger. Blanchot's phenomenology of art seems to be couched in terms ("earth," "sky") that Heidegger had made familiar in "Das Ding" (1950). ${ }^{4}$ Yet it also contests those very terms, for it consists in indicating something other

4 See Martin Heidegger, “The Thing” (1971, 171). Levinas is of course aware of this aspect of Blanchot’s thought. See Levinas, “The Poet’s Vision” $(1996,137)$. 
than the truth of being, as Heidegger would have it, namely, that mysterious excluded middle he calls the "Neutral" or the "Outside." It would be better to say, then, that Blanchot offers a counterpart to phenomenology, for the Outside only ever approaches and never appears as such.

There are at least two reasons why Levinas might take umbrage with his friend. In the first place, he might well hear, a little too quickly, Heidegger's word Eigentlichkeit whispered behind Blanchot's authenticite. ${ }^{5}$ Blanchot does not use the word to translate Heidegger's German in Sein und Zeit (1927), for he does not look to that which is true (or genuine) or to the true state of being but rather to that which escapes both "truth" and "being." Nor does he distance himself sufficiently for Levinas from the Heidegger who thinks that Dasein is in each case mine, and for whom Mitdasein and Miteindersein are derivative of Dasein. ${ }^{6}$ The truth that the other person's face silently commands "Do not kill me!," along with the moral seriousness of this command, are not acknowledged. In the second place, Levinas, as advocate of ethics as first philosophy, recoils from Nietzsche's view, adapted by Blanchot, that with the abolition of the "real world" the "apparent world" also crumbles. ${ }^{7}$ Henceforth, for Blanchot, to live authentically in accord with an uncompromising nihilism one must look to the non-serious and the non-true, which derive from the approach of the Outside. This is the view of thoroughly demystified existence that one finds elsewhere affirmed as "the ultimate insignificance of lightness” [l'ultime insignifiance de la légèreté] (Blanchot 1993b, 43), and that troubles the self-ordering of the Heideggerian city.

Reflecting on Levinas's sharp reaction to Blanchot's note, we begin to see that the philosopher does not grasp all the aspects of the notion of the Outside that he acclaims. He affirms its status as an excluded middle, a third that frustrates any dialectical drive to totality, yet fails to appreciate how strongly it conflicts with his own views. For Blanchot, the Outside can be discerned in various ways: in ordinary suffering, when time seems to stall; in the midst of the everyday; and in intransitive - literary - writing; yet also in the ceaseless oscillation of being and non-being, which happens when something becomes an image of itself. For him, this awareness of the relation between being and non-being signals the approach of the non-world of image, a neutral state that can only fascinate us and, in doing so, bind us to itself. Yet it cannot concern us; it does not offer itself to us by way of experience, only as something impossible to bring into that realm, and therefore comes to be dubbed "the impossible." ${ }^{8}$ Levinas

5 See Heidegger, Being and Time $(1973,167)$.

6 See Heidegger, Being and Time $(1973,68)$.

7 See Friedrich Nietzsche, “How the 'Real World' at last Became a Myth” $(1968,41)$.

8 See, for example, Blanchot, The Infinite Conversation (1993a, 45-48). 
had already rejected that specter in no uncertain terms in "La réalité et son ombre" where he recognizes that it precedes the workaday world of initiative and action, and thereby has the ability to mire characters in a temporal "meanwhile" and to hold readers immobile before it. ${ }^{9}$ In some respects, it resembles what he calls the il y $a$ at about the same period, the inability to cancel being, for even when something is absent, even permanently absent, one nonetheless intuits the presence of that absence. ${ }^{10}$ For Levinas, one escapes the il $y$ a by responding to another person, and yet it seems that for Blanchot that avenue is not available. Certainly, in "Exercises on 'The Madness of the Day", Levinas comes to affirm what he calls the "extra-vagant" $(1996,170)$ dimension of narrative, and his hyphen recalls the Latin patrimony of the French - extra ("outside") and vagari ("wander") - yet he does so without fully endorsing, perhaps without fully realizing, what motivates Blanchot's affirmation of radical error in literature.

Of course, Levinas in quite right to say in "Le regard du poète" (translated as "The Poet's Vision") that the Blanchot of L'Espace littéraire abstains "from ethical preoccupations, at least in explicit form” $(1996,137) .{ }^{11}$ When Blanchot turns to consider ethics more directly it will be in terms of an adjustment of the program of Totalité et infini (1961) by way of the Outside. He will not accept that the asymmetry of the other person with respect to me is properly basic. ${ }^{12}$ One important step on the path to this discussion will be the writing of "Comment découvrir l'obscur?” (1959), in which Blanchot will indicate a peculiar phenomenology of this Outside, of something quite other than light and being, and this will enable him to chart a different course from the one that Levinas undertakes in his insistence that ethics, as first philosophy, revolves around the other person as enigma, rather than as phenomenon. ${ }^{13}$ When the other person speaks to me I hear the irreducible strangeness of the Outside, and that strangeness orients me to think of community rather than any individual.

Yet in 1975 Levinas finds an ethical moment, a call for justice, in La folie $d u$ jour, and makes it the thesis of his reflections on the récit. His main idea is, as

9 See Levinas, "Reality and Its Shadow" (2004, 84-89).

10 See Levinas, Existence and Existents (1988, chapter 4).

11 Blanchot's post-war left-wing political commitments are evident, though, in at least one text that precedes the publication of this book. See Blanchot, "Dionys Mascolo: Le Communisme" (1953).

12 See Blanchot, “Tenir parole” (1962) and "L’Interruption" (1964). The first "dialogue” and part of the second were republished in L'Entretien infini (1969, 84-93, 106-112).

13 See Blanchot, “Comment découvrir l'obscur” (1959), reprinted in L'Entretien infini (1969, 57-69). Also see Levinas, "Phenomenon and Enigma” (1987). 
he says, that even though texts are always open to various interpretations, "the irreducible (inspired) exoticism of poetry refers back to [en appelle à] a saying properly so-called, a saying that thematizes, even if it may be obliged to unsay itself in order to avoid disfiguring the secret it exposes" (Levinas 1996, 157). Actually, he goes further than this claim in his fourth exercise, finding in the récit "a way out" of the endless suffering of the human condition, co-ordinate with interiority. This interiority is one with "the closure of being" (Levinas 1996, 158), the Western obsession with being which runs from Parmenides to Heidegger and which he had identified as early as De l'évasion (1935). This exit is found, he says, by developing a "relation to the other" (Levinas 1996, 165). Is his reading of the récit justified?

When we see that Levinas entitles his commentary "Exercises" we might, at a pinch, think of Epictetus's two-stage model of philosophical education. First, we master theory and then, through spiritual exercises, seek to apply it to our own lives. ${ }^{14}$ And we might entertain the idea that he is led to title his piece in this manner because of a Stoic element in La folie du jour. For we are told, almost at the very start, "this life gives me the greatest pleasure. And what about death? When I die (perhaps any minute now), I will feel immense pleasure . . . I experience boundless pleasure in living, and I will take boundless satisfaction in dying" [cette vie me fait le plaisir le plus grand. Alors, la mort? Quand je mourrai (peut-être tout à l'heure), je connaîtrai un plaisir immense ... j'éprouve à vivre un plaisir sans limites et j'aurai à mourir une satisfaction sans limites] (Blanchot 1981, 5). Yet Stoic pedagogy also rings very faintly in the idea of a schoolboy's exercise: Levinas, remember, was Director of the École Normale Israélite Orientale (ENIO) from 1945 to 1961. ("Exercises on 'The Madness of the Day," however, would be an unorthodox example of pedagogy, written, as it is, in jagged French and moving in a halting manner, at once overly compressed and sometimes unclear in its passage from sentence to sentence.) Also, while Blanchot's narrator claims to be indifferent to the accidents of life and death, his tranquility does not seem to have been brought about by adherence to virtue for its own sake and one does not look even to Seneca for finding satisfaction in death; at the most one's demise brings release from desire and pain. ${ }^{15}$ And yet perhaps an echo of Stoicism is not a mere distraction, at least with regards to Levinas, as we will see.

14 See Epectetus, Dissertationes, 1. 26. 3. Also see Musonius, Dissertationum a Lucio Digestarum Reliquiæ, 6.

15 Blanchot, in The Space of Literature, distances himself from Stoicism (1982, 101). Also see Seneca, Epistulæ Morales ad Lucilium, 12.4. 
Appropriately enough, Levinas begins by commenting on the title of the récit: "Madness of today, but madness of the day also in the sense that, in it, day is madly desired, and in the sense that day - clarity and measure goes made there, and, hence, especially, in the sense that the madness of day is contrasted with the madness or panic of night" (Levinas 1996, 158). Perhaps it needs to be brought out a little more strongly that the expression "folie $d u$ jour" also names the madness or extravagance of light, especially of daylight. Exactly what "folie" means for Levinas, and for Blanchot, for there is no reason to think that they agree at all points, is left unmarked; but let us remain with "jour" for the moment. To which day or days does it refer? Not to France after the Occupation, Levinas says, but rather it "seems to bear a greater resemblance to 1968 " $(1996,159)$, a claim to which he returns ("inanity and madness, twenty years later" $(1996,169))$ but which is left to dangle, even while we recall the remark about "the lack of seriousness of edification." Levinas continues: "These pages do not even reflect what was going on in 1948 on the level of the history of ideas. . . The Madness of the Day might therefore be said to be free from any temporal limitations" $(1996,159)$.

If $L a$ folie du jour does not take on one or another of the primary philosophical colors of post-Liberation Paris - neither that of Camus, Marcel, and Sartre, nor that of Raymond Aron - it certainly is of a piece with Blanchot's own itinerary. "Un récit" was composed in the midst of dense reflection on Lautréamont, Sade, and Hölderlin, texts in which the question of madness is seldom absent, even when not explicitly posed..$^{16}$ One might look, for instance, to the very end of "L'Expérience de Lautréamont" (1948), parts of which appeared over the same few months that saw the publication of "Un récit." Blanchot concludes his long essay by comparing Hölderlin and Lautréamont. The German poet, he thinks, was "truly and absolutely united with the light to which he had the strength to sacrifice all his forces and that, in return, brought him this unique glory of a child's reasoning wherein all the splendor of impersonal clarity shines forth" (Blanchot 2004, 163). ${ }^{17}$ The French poet, however, "was unable to disappear within madness, being born of madness." He too had the "force of light within him" which was "an unlimited aspiration, which the extreme moment designates the sole, ideal and real point at which, ceasing being himself, he can become, outside of himself, completely himself, in the end coming

16 For the importance of Hölderlin to Blanchot's récit, especially the essay "La Parole 'Sacrée' de Hölderlin” (1946), see Leslie Hill, Blanchot: Extreme Contemporary (1997, 95-102).

17 Also see Blanchot, "La Folie par excellence” (1951). 
forever into the world at the ultimate moment that makes him disappear from it” (Blanchot 2004, 163-164).

Connections between light and madness are at the very heart of La folie $d u$ jour, but we would do well to approach them with caution. We first hear of madness when the narrator recalls having lost people he has loved, presumably in the recent war: "I went mad when that blow struck me, because it is hell" Ue suis devenu fou quand ce coup m'a frappé, car c'est un enfer] (Blanchot 1981, 6, 20). Indeed, the war is characterized directly thereafter as "the madness of the world" [la folie du monde] (Blanchot 1981, 6, 20). Note, though, that the extreme moment of that violence, when the narrator is almost executed, is precisely the point when he stops "being insane" [être insensé] (or foolish, senseless ....)] (Blanchot 1981, 6, 20). ${ }^{18} \mathrm{He}$ appears to be on an even keel when later "a lunatic" [un fou] (Blanchot 1981, 8, 22) stabs him in the hand and, still later, again for no apparent reason, another person crushes glass in his eyes. After that second event he becomes convinced that [he] is "face to face with the madness of the day" [je fus convaincu que je voyais face à face la folie du jour] (Blanchot 1981, 11, 25). This is no sudden vision but rather a making evident of the truth of a situation, regardless of whether the judgment is made correctly or incorrectly. When recovering from his injury in half-light, the narrator longs for daylight, which would be perfectly normal: "and if seeing would infect me with madness, I madly wanted that madness" [et si voir c'était la contagion de la folie, je désirais follement cette folie] (Blanchot 1981, 12, 25). It is an extreme desire, to be sure, yet I draw attention to the "et si"; he has not lost his power of reason or perhaps the power to feign reason. Finally, after the narrator agrees to be locked up, one of the doctors sees another inmate, an old man with a white beard, jumping on his shoulders and hears the narrator say, impatiently, “Who are you, Tolstoy?” [Tu es donc Tolstoi?] (Blanchot 1981, 16, 29), which makes the doctor think (according to the narrator) that he is "truly crazy" [bien fou] (Blanchot 1981, 16, 29). But we are not invited to trust the doctor's supposed judgment. (Presumably, he does not know Tolstoy's On Insanity, to which the narrator most likely alludes. We read there something that he might well recall: "Recently I happened to visit two large establishments for the mentally deranged, and the impression I received was that I saw establishments built by mentally deranged people suffering from one common epidemic form of lunacy, for patients suffering from different forms of lunacy which do not resemble the common epidemic form" (Tolstoy 1936, 31).) And when, at the very end, "a specialist in mental illness" [un spécialiste des maladies mentales] (1981

18 Blanchot recounts the attempted execution in his The Instant of My Death (2000). 
$18,31)$ interrogates the narrator, we have no particular ground to think that the specialist is called for.

One should take care before saying that the narrator is clinically mad, and should certainly consider his black humor, which tends to deflate situations: for example, le sang dégouttait sur mon unique costume ["the blood was dripping on my only suit"] (Blanchot 1981, 22, 8), he says in response to having his hand cut with a knife, and C'étaient de joyeux moments ["Those were happy times"] (Blanchot 1981 29, 16), which he remarks by way of concluding the episode of his being beaten by inmates in the hospital. Also, one should be circumspect in categorically denying that the narrator is a little touched; the mad can sometimes appear quite reasonable if one accepts the confines of their disorder, and this man experiences delirium when seeing a perfectly ordinary occurrence: the conjunction of a woman with a pram and a man entering a building. He interprets this banal event eschatologically. "Here it comes, I said to myself, the end is coming: something is happening, the end is beginning" [Voici qu'elle arrive, me disais-je, la fin vient, quelque chose arrive, la fin commence] (Blanchot 1981, 10, 24). Equally eccentric is his reaction to facing the end: "I was seized by joy" [J'étais saisi par la joie] (Blanchot 1981, 10, 24). And yet we have been prepared for this sort of response from the opening paragraph: "I will take boundless satisfaction in dying" [j'aurai à mourir une satisfaction sans limites] (Blanchot 1981, 5, 19).

Is there other evidence than the direct allusions to folie in the récit that should be taken into account before coming to a conclusion? There is: the second figure of the law as recounted in the latter part of the story. We hear that the narrator was “attracted to the law" [la loi m'attirait] (Blanchot 1981, 9), perhaps as a profession, or perhaps he found her charming. (We know already that he prizes women, "beautiful creatures" [belles créatures] (Blanchot 1981, 7, 21), for their equal acceptance of life and death.) In any case, it is abnormal for someone to call to the law, "Come here; let me see you face to face" [Approche, que je te voie face à face] (Blanchot 1981, 9, 22). Only Moses, who receives the Law from the Most High and talks with him "face to face" and "mouth to mouth," comes to mind (Exod. 33: 11, Num. 12: 8). The law, in La folie du jour, would be what Levinas comes to call autrui, higher than the one addressing her, but of course she does not respond, for which the narrator is thankful. (A little later we hear the narrator seeing the madness of the day "face to face" (Blanchot 1981, 11), but it too cannot be autrui, despite its height.) The narrator declines engaging with the law by not suing the man who crushed glass in his eyes, and disapproves of a doctor who litigates a patient who fooled him by taking a drug without telling him. In addition, he dislikes thinking of his various talents as judges "ready to condemn" him [prêts à me condamner] 
(Blanchot 1981, 14, 27), and, from the beginning, observes the power of the medical profession, which imposes its own protocols on him regardless of the pain it causes him. Yet the most disturbing evocation of the law comes when the doctors, who act as kings, are interrogating him. "Behind their backs I saw the silhouette of the law. Not the law everyone knows, which is severe and hardly very agreeable: this law was different" [Derrière leur dos, j'apercevais la silhouette de la loi. Non pas la loi que l'on connaît, qui est rigoureuse et peu agréable: celle-ci était autre] (Blanchot 1981, 14, 28). His former attraction to the law, the first law, must have faded.

How is this second law different? Because the narrator seems "to terrify her" (Blanchot 1981, 15); she is "perpetually on her knees" before him (Blanchot 1981, 15), as though he is now auturi. At times their relationship has the character of une folie, a fling. "Once she had made me touch her knee - a strange feeling. I had said as much to her: 'I am not the kind of man who is satisfied with a knee!' Her answer: 'That would be disgusting!'” [Elle m'avait une fois fait toucher son genou: une bizarre impression. Je le lui avais déclaré: Je ne suis pas homme à me contenter d'un genou. Sa réponse: Ce serait dégoûtant!] (Blanchot 1981, 16-17, 30). Certainly, the first sight of the law has a romantic element to it. The narrator sees her in silhouette - a black and featureless shadow - as if in a scene in a film noir of the period, and if we take the narrator, being neither learned nor ignorant, as fulfilling Diotima's requirement for being a lover, we should not be surprised at this turn of events. ${ }^{19}$ Of course, an unusual light would be needed to produce a silhouette of the law, something that contrasts sharply with its exteriority. Call it the light of consciousness. There is some textual support for the claim, since the law takes the narrator's gaze to be "a bolt of lightning" [la foudre] (Blanchot 1981, 15, 28), recognizing, perhaps, what Derrida was to remark years later with respect to Levinas, that phenomenology relies on "the violence of light."20

If we closely follow what the law says to the narrator, we find that she sets him above authority, that she praises him outrageously, that she commends justice to him, that the two of them are forever bound together, and that she is intent upon his glory. I take it that the silhouette of the law, which is all the narrator sees, is a figure for writing, which, for Blanchot, contests all rules, plays games - “ce jeu insensé d'écrire,” as Mallarmé says, and as Blanchot likes to quote - creates an author only to let him fade the moment he stops writing,

19 See Plato, Symposium, 204a. On this motif, see Sarah Kofman, Comment s'en sortir? (1983, 97-98).

20 See Derrida, "Violence and Metaphysics: An Essay on the Thought of Emmanuel Levinas" (1978, 84-92). 
remains forever bound to the one who writes, converges with left-wing demands for justice, and that forever is capable of resurrecting his consciousness, whether he is alive or dead, in a ghostly half-life. ${ }^{21}$ Writing is the silhouette of the Outside, which our mundane laws seek to contain and which nonetheless irrupts through them and imposes its own law on us in various ways.

Madness, for Blanchot, is therefore several things at once: insanity, experience of the measureless light of divine inspiration, whether as a return to childhood or as an extravagant struggle to overcome constraints, and erotic adventure. It is also the "absence of work," not simple laziness but désœuvrement, in which a text or a person resonates with the Outside in its approach and becomes disengaged from any dialectic. In that absence of work, we are told by Blanchot in 1960, "discourse ceases, so that, outside speech, outside language, the movement of writing may come, under the attraction of the outside"(1993a, 32). ${ }^{22}$ This is madness in the sense of being unhinged from an established order.

Levinas is attentive solely to the last of these senses of "madness," which in "Exercises on "The Madness of the Day" he regards as a symptom of the "closure of being," a "hellish unfreedom" (Levinas 1996, 159), a suffocation in selfhood that "lurks at the very heart of the joys, the day, and the unshakable happiness described in the opening lines of our text" (Levinas 1996, 160). He approaches this madness under the sign of weariness:

Weariness [la fatigue] keeps recurring in the text; the void fills itself with itself, repose doesn't settle down. Weariness [Lassitude] - precisely. There is no progressive dialectic, in which the moments of the story spring up in their newness, before contracting their freshness by all they conserve. The circular return of the Identical does not even follow a long-term cycle. It is a twirling on the spot: happiness is obsessed in its very permanence, the outbreak of madness sinks back into madness, into oppression, into an unbreathable interiority without exterior. Is madness a way out, or is the way out madness?

(Levinas 1996, 161-162)

Levinas's concern with the "presence of the present" being "immobilized" $(1996,159)$ is familiar to readers of "La réalité et son ombre" $(1948)$; it is at the hub of his criticism of art. And the inability of someone to break free from the fatigue associated with the il y $a$ is of course a dominant them of De l'existence à l'existant (1947). If La folie du jour does not, for Levinas, "reflect what was

21 Stéphane Mallarmé, "Villiers de l'Isle-Adam” (2003, 23). Also see the conclusion of Blanchot's "Dionys Mascolo: Le Communisme” (1953).

22 See Blanchot, "La Marche de l'écrivisse," (1960, 93). 
going on in 1948" (1996, 159), it seems to resonate with precisely what he was thinking and writing at that time. He does not seem to recognize this as a "temporal limitation" of the story, however.

In the late 1940s Levinas recognized that the only way of escaping the stultifying oppression of the il y a was to leave the suffocating solitude of the self and move towards the Good, which can occur only when one salutes another person and recognizes and values his or her irreducible otherness. Madness is not the way out of banal existence, as it was for Artaud and van Gogh, and before them the Breton of Nadja (1928), let alone for proponents of Dionysian excess such as Bataille. Rather, a rethinking of philosophy - so that ethics, not metaphysics, is first philosophy - will indicate that exit, and this turning upside-down of the intellectual world doubtless seemed to some of Blanchot's contemporaries to be nothing short of madness. In order to assimilate La folie $d u$ jour to his own thought, Levinas must find a "way out" that is delineated in the story. The fourth exercise does precisely that. "Relation to the other - a last way out. From one end to the other of the story, this relation is present" (Levinas 1996, 165). He points to the narrator's experience of the loss of loved ones, which causes the narrator such pain, but gravitates on one brief scene, which I have already mentioned. "The little scene in which, in front of the courtyard door, a man steps back to let a baby carriage through, is the event of an advent - that is, the moment when something abnormal ensues: one person withdraws before the other, one is for the other. Whence the narrator's lightheartedness, which seems to lift him above being” (Levinas 1996, 165-166). Let us look more closely at this scene.

The narrator certainly sees the man think twice and step aside so that a woman can enter a door with a pram. Notice, though, that the narrator does not do anything except observe, and while it has extraordinary significance for him - it "excited me to the point of delirium" [me souleva jusqu'au délire] (Blanchot 1981, 10, 24) - exactly what it means is beyond him. The man who steps aside is "for the other," we might agree, and we might think of this by way of la transascendance, but we have no reason to say the same of the narrator. ${ }^{23}$ He merely enters the courtyard after the woman has disappeared, takes in how very cold it is, and lingers there "in the joy and perfection of this happiness" [la joie et la perfection de ce bonheur] (Blanchot 1981, 10, 24). Far from seeing moral action as an exit from his situation, the narrator remains

23 The word "transascendance" was coined by Jean Wahl and taken up by Levinas. See Wahl, Existence humaine et transcendance $(1944,37)$ and Levinas, Totality and Infinity: An Essay on Exteriority (1979, 35 note 2). 
pleasurably within himself. What strikes him is not the goodness of the event he has witnessed but its reality, and that the day "having stumbled against a real event, would begin hurrying to its end" [ayant buté sur un événement vrai, allait se hâter vers sa fin] (Blanchot 1981, 10, 24). In case we overlook the statement, the narrator underlines it in the very next paragraph, "All that was real; take note" [Tout cela était réel, notez-le] (Blanchot 1981, 11, 24). Reality, for the narrator, would seem to be purely sensory. The only thing he dislikes about the prospect of dying is that "Suffering dulls the senses [or 'stupifies']" [Souffrir est abrutissant] (Blanchot 1981, 6, 19). He says, "I see the world - what extraordinary happiness! I see this day, and outside it there is nothing" [je vois le monde, bonheur extraordinaire. Je le vois, ce jour hors duquel il n'est rein] (Blanchot 1981, 6, 20); in other words, all that there is is sensory: no past, no future, and surely no transcendent realm. What disturbs him most of all about the medical experiment of covering him with mud is that "My sense of touch was floating six feet away from me" [Mon tact errait à deux mètres] (Blanchot 1981, 7, 21). Immediately before the scene of the woman with a pram, "the gloomy spirit of reading" [sombre esprit de la lecture] (Blanchot 1981, 9, 23) insults him and, being at a low point, he could not even have answered the question "Who was I?" [Qui étais-je?] (Blanchot 1981, 10, 23). (Of course, it can be a hard question to answer even if one is at a high point in life. ${ }^{24}$ ) So when he sees the woman, the pram, and the man, when he feels the cold in the courtyard, he is impressed by the sensuous reality of these things; they have a solidity that the realm of spirit does not have. Time seems to click into gear once more; if it has stalled with the encounters with the lunatic and the spirit of reading, and with a loss of selfhood, it now picks up speed and finds a direction.

I return to Levinas's remarks on weariness as a dominant motif in La folie $d u$ jour, at least until the narrator sees the woman with a pram. Now the narrator does not speak of fatigue; on the contrary, his testimony is given with noticeable vigor, returning time and again to declarations given in the firstperson ("I am not learned; I am not ignorant" [Je ne suis ni savant ni ignorant] (Blanchot 1981, 5, 19), "I have wandered" [J'ai erré] (Blanchot 1981, 5, 19), "I have loved people" [J'ai aimé des êtres] (Blanchot 1981, 6, 20), "I am not timid" [Je ne suis pas craintif] (Blanchot 1981, 8, 22), "I must admit I have read many books" [Je dois l'avourer, j'ai lu beaucoup de livres] (Blanchot 1981, 9, 22) and so on) or posing questions in order to answer them ("Is my life better than other people's lives?" [Mon existence est-elle meilleure que celle de tous?]

24 See, for quite different examples, Blaise Pascal, Pensées (2005, S567/L688), and André Breton, Nadja $(1928,7)$. 
(Blanchot 1981, 6, 20), “Can I describe my trials?” [Puis-je décrire mes épreuves?] (Blanchot 1981, 7, 21) “Am I an egoist?” [Suis-je égoïste?] (Blanchot 1981, 8, 21)). Almost frenetic, the testimony lurches from one statement or evocation to another, sometimes so briefly as to perplex the reader as to its significance for either the narrator or the story he is telling. The episode of the woman with a pram is exemplary here; and yet the narrative runs on, past this episode, as though seeking a dénouement. Throughout, the narrator appears to be distanced from the very events he undergoes. It is less a matter of alienation from the world than something stranger: a sense of not having any agency, of being thrown from one event to another, which results in the staccato narrative. It is this relentless self-interrupting of the narrative by the narrator himself that becomes the true "subject" of La folie du jour, a technique that Blanchot probably learned from Kafka. ${ }^{25}$ It reaches its apotheosis when, at the end, the narrator begins to retell his story. There is a disjunction between events we presume to have occurred (but which are perhaps taking place only in the story) and the significance of them for those who know who they are and who embody institutional power. For the narrator, some of those events, the ones that most interest the medical world, may have been lived through but not at the center of his consciousness. They fall outside the bounds of his story.

So we only apparently reach a point when the plot becomes unlaced, which is when the narrator has glass crushed into his eyes, for we are never told who injures him or why. The shards of glass seem to intensify the daylight, making it as though immediate and without measure, and when they are removed he must rest with a film under his eyelids for seven days - the biblical number of fullness, and especially of the seven seals in Revelation which becomes for him "the spark of a single moment" [la vivacité d'un seul instant] (Blanchot 1981, 11, 25). ${ }^{26}$ Notice that the narrator takes himself to be called "to account" [comptes] in that week, yet his judges, the seven days, perhaps a metaphor for the seven angels of Revelation, who act as one, light itself, are mad and without any restraint. On waking in hospital, the very idea of engaging with a lesser law - that of suing for special or general damages strikes him as risible; and in his convalescence, when he must wear dark glasses, he finds that he would experience the fire of the seven days, the

25 See Blanchot, The Infinite Conversation (1993a, 384). On the nature of the récit, see Blanchot, "The Song of the Sirens" $(2003,6)$.

26 It is worth noting that for Levinas an immediate contact with the sacred, without the mediation of reason, would be an instance of la folie. See Levinas, "To Love the Torah More than God” (1990, 144). 
transcendent luster of the seven angels, again if only he could see properly. In seeing that the days or angels are without ground, the narrator is unmoored from the usual anchors, ropes and cables, undergoes désœuvrement, and so disorientation becomes his task.

It seems then that the Outside is acknowledged in two distinct ways in $\mathrm{La}$ folie $d u$ jour. One recognizes its approach in the distance between the "I" and the apparently random events that occur to him, which becomes a distance within himself, dividing him from himself. The narrator does not experience this disunion by way of fatigue, however, although such a thing is possible. In a later récit attuned to weariness a speaker ironically observes, perhaps to himself, that he is too fatigued to affirm that weariness can prompt a reduction to the non-world of the Outside. He simply overhears, as it were, a voice whispering that it is so, a voice that is close to the Outside:

Do you really believe you can approach the neutral through weariness, and through the neutral of weariness, better hear what occurs when to speak is not to see? I do not believe it, in fact; I do not affirm it either. I am too weary for that. Only, someone says this close to me, someone I do not know; I let them talk, it is an inconsequential murmur. [Crois-tu vraiment que tu puisses t'approcher du neutre par la fatigue et, par le neutre de la fatigue, mieux entendre ce qu'il arrive, quand parler, ce n'est pas voir? Je ne le crois pas, en effet; je ne l'affirme pas non plus; je suis trop fatigué pour cela; quelqu'un, seulement, le dit près de moi, que je ne connais pas; je le laisse dire, c'est un murmure qui me tire pas à conséquence.]

(Blanchot 1993a, xx-xxi)

Yet if the Outside is indicated in a passive non-relation to oneself, it also presents a counterpart to itself in sheer intensity, in being "face to face" with a mad light: the Most High is revealed to be crazy, like the doctors as Tolstoy sees them, and in any case hiding us from the Outside as it truly gives itself (in withdrawal). Even here, in this false encounter with the Outside, the narrator bespeaks a distance from himself: "At times I said to myself, 'This is death. In spite of everything, it's really worth it, it's impressive”" [Parfois, je me disais: 'C'est la mort; malgré tout, cela en vaut la peine, c'est impressionnant] (Blanchot 1981, 11, 25).

Levinas writes on La folie du jour in 1975. Some years before then Blanchot had devoted several dialogues to his friend's mature thought in Totalité et infini (1961). One of the voices in "Tenir parole" (1962) ponders the relation between "myself” and Autrui. Of this relationship, one voice says, "Emmanuel Levinas would say that it is of an ethical nature, but I find in this word only secondary meanings. That autrui should be above me, that his speech should be a speech of height, of eminence - these metaphors appease, by putting it into perspective, a difference so radical that it escapes any determination 
other than itself" (Blanchot 1993a, 63). The primary meaning of the encounter with another person is given in speech when it is figured as primary, not derived from sight. Another dialogue, "L’Indestrucible” (1962), augmented in L'Entretien infini (1969), argues that I and another person subsist in a "third relation," given neither by way of dialectic nor by way of absorption by the other person. This third relation holds the two parties together and apart in the activity of speech; it is, as he says, "the very extent of the Outside" (Blanchot 1993a, 69). He goes on to erode Levinas's claim that the ethical height of another person is a phenomenological given, insisting that the other person and I abide in a relation of double dissymmetry, one that does not flatten the ethical sphere into a plane, and rephrasing the object under scrutiny from Autrui to the community (Blanchot 1993a, 70-71). ${ }^{27}$ In short, Blanchot is clear that there is no exit from the Outside, and that it is only by way of the Outside that one can properly encounter another person: we may speak of justice but only if we do so in the awareness that it derives from a more fundamental situation than ethics ever countenances. For what is crucial is not meeting the other person as a stranger but regarding him "as a man in his strangeness - that which escapes all identification"(Blanchot 1993a, 74).

To be sure, Blanchot's understanding of the Outside develops over the years from 1948 to 1969, in part through the intellectual rapport he has with Levinas's philosophy. Yet it does not change in major ways. The conversations about Levinas's magnum opus at the start of L'Entretien infini can be read as an oblique response to his reservations about L'Espace littéraire. Yet in "Exercices sur 'La folie du jour"” Levinas makes no reference to this response, and writes as though Blanchot were following the philosophical position outlined in De Existence à la existent. Levinas wonders if he might be accused on "lès-poésie" in his reading of La folie du jour, because he plans to consider only a few passages of it and respond to their texture $(1996,157)$. But the charge would be more surely justified on the ground that Levinas does not acknowledge the story's affirmation of the inescapability of the Outside. In the end, Levinas does not read La folie du jour; he applies his own philosophy to it, seeing there a story written by a version of himself, perhaps the novelist he never became, and not the story written by his friend Blanchot.

27 The difficulty of thinking community is explored by Blanchot in The Unavowable Community $(1988,12)$. 


\section{Bibliography}

Blanchot, Maurice. 1951. “La Folie par excellence.” Critique 45 (February 1951): 99-118.

Blanchot, Maurice. 1953. "Dionys Mascolo: Le Communisme.” La Nouvelle Revue française 12 (December 1953): 1096-1099.

Blanchot, Maurice. 1959. “Comment découvrir l'obscur." La Nouvelle Revue française 83 (1959): 867-879.

Blanchot, Maurice. 1960. “La Marche de l'écrivisse.” La Nouvelle Revue française 91 (July 1960): 90-99.

Blanchot, Maurice. 1962. "Tenir parole.” La Nouvelle Nouvelle française 110 (February 1962): 290-298.

Blanchot, Maurice. 1964. “L’Interruption.” La Nouvelle Nouvelle française 137 (May 1964): 869-881.

Blanchot, Maurice. 1969. L'Entretien infini. Paris: Gallimard.

Blanchot, Maurice. 1981. The Madness of the Day. Trans. Lydia Davis. Barrytown: Station Hill Press.

Blanchot, Maurice. 1982. The Space of Literature. Trans. Ann Smock. Lincoln: University of Nebraska Press.

Blanchot, Maurice. 1988. The Unavowable Community. Trans. Pierre Joris. Barrytown: Station Hill Press.

Blanchot, Maurice. 1993a. The Infinite Conversation. Trans. Susan Hanson. Minneapolis: University of Minnesota Press.

Blanchot, Maurice. 1993b. The One Who was Standing Apart from Me. Trans. Lydia Davis. Barrytown: Station Hill Press.

Blanchot, Maurice. 2000. The Instant of My Death, bound with Jacques Derrida, Demeure. Trans Elizabeth Rottenberg. Stanford: Stanford University Press.

Blanchot, Maurice. 2003. "The Song of the Sirens." The Book to Come. Trans. Charlotte Mandell. Stanford: Stanford University Press. 1-24.

Blanchot, Maurice. 2004. Lautréamont and Sade. Trans. Stuart Kendall and Michelle Kendall. Stanford: Stanford University Press.

Breton, André. 1928. Nadja. Paris: Gallimard [reprint 1945].

Derrida, Jacques. 1978. "Violence and Metaphysics: An Essay on the Thought of Emmanuel Levinas." Writing and Difference. Trans. Alan Bass. London: Routledge and Kegan Paul. 79-153.

Derrida, Jacques. 2011. “Title to be Specified.” Trans. Tom Conley. Parages. Ed. John P. Leavey. Stanford: Stanford University Press. 192-215.

Heidegger, Martin. 1971. “The Thing.” Poetry, Language, Thought. Trans. Albert Hofstadter. New York: Harper and Row. 165-186.

Heidegger, Martin. 1973. Being and Time. Trans. John Macquarrie and Edward Robinson. Oxford: Basil Blackwell.

Hill, Leslie. 1997. Blanchot: Extreme Contemporary. London: Routledge.

Kofman, Sarah. 1983. Comment s'en sortir? Paris: Galilée.

Levinas, Emmanuel. 1979. Totality and Infinity: An Essay on Exteriority. Trans. Alphonso Lingis. The Hague: Martinus Nijhoff.

Levinas, Emmanuel. 1987. "Phenomenon and Enigma." Collected Philosophical Papers. Trans. Alphonso Lingis. Dordrecht: Martinus Nijhoff. 61-74. 
Levinas, Emmanuel. 1988. Existence and Existents. Trans. Alphonso Lingis, corrected edition. Dordrecht: Kluwer.

Levinas, Emmanuel. 1990. "To Love the Torah More than God.” Difficult Freedom: Essays on Judaism. Trans. Seán Hand. Baltimore: Johns Hopkins University Press. 142-145.

Levinas, Emmanuel. 1996. On Maurice Blanchot, bound with Proper Names. Trans. Michael B. Smith. Stanford: Stanford University Press.

Levinas, Emmanuel. 2004. "Reality and Its Shadow." Unforeseen History. Trans. Nidra Poller. Urbana: University of Illinois Press. 76-91.

Levinas, Emmanuel. 2009. Oeuvres, 1: Carnets de captivité et autre inédits. Eds. Rodolphe Calin and Catherine Chalier. Paris: Grasset.

Mallarmé, Stéphane. 2003. "Villiers de l'Isle-Adam" Oeuvres complètes, 2 volumes. Bibliothèque de la Pléiade. Ed. Bertrand Marchal. Paris: Gallimard.

Nietzsche, Friedrich. 1968. "How the 'Real World' at last Became a Myth." Twilight of the Idols, bound with The Anti-Christ. Trans. R. J. Hollingdale. Harmondsworth: Penguin.

Pascal, Blaise. 2005. Pensées. Ed. and Trans. Roger Ariew. Indianapolis: Hackett Pub. Co., 2005.

Tolstoy, Leo. 1936. On Insanity. Trans. Ludvig Perno. London: C. W. Daniel.

Wahl, Jean. 1944. Existence humaine et transcendance. Neuchâtel: Éditions de la Baconnière. 
